\title{
A RETROSPECTIVE ON THE WOODHOUSE REPORT: THE VISION, THE PERFORMANCE AND THE FUTURE
}

\author{
Rt Hon Sir Geoffrey Palmer QC*
}

\begin{abstract}
The following is a revised version of the second Woodhouse Memorial Lecture given at both the Victoria University of Wellington and the University of Auckland in September 2018. It traces the history and policy iterations of New Zealand's accident compensation scheme that flowed from the 1967 Woodhouse Report (the Report), a Royal Commission report chaired by Sir Owen Woodhouse. It discusses the features of the Report and the determination it showed to get rid of the common law action for damages for personal injury. It analyses the degree to which the Report was not followed in the journey it took through the political decision-making system. There is a critical analysis of the delivery of benefits, the administration of the scheme and its financing. The performance in accident prevention and rehabilitation is briefly covered. The method of settling disputes in the scheme has seen an unwelcome return to legalism. The lecture concludes with a strong plea to remove the anomalies created by the accident compensation scheme between the vicitims of accident who receive earnings related-benefit and those who are dealt with under the Social Security Act 2018 under which they receive flat rate benefits. The lecture concludes with some lessons for policymakers.
\end{abstract}

\section{INTRODUCTION}

This lecture is part of a Festschrift for Professor Gordon Anderson who has given sterling service to the Victoria University of Wellington. He has specialised in employment law and the regulation of labour and work. This field used to be the responsibility of the Department of Labour in New Zealand, now merged into the Ministry of Business, Innovation and Employment. The history of the Department of Labour, particularly in its earliest days, was notable for radical and world leading reforms. It was from that Department that the accident compensation scheme emerged. Accident compensation was world leading. So there is a vital connection between the academic career of Gordon Anderson and the contents of this lecture.

* Distinguished Fellow, Victoria University of Wellington, Faculty of Law; and Global Affiliated Professor, University of Iowa, College of Law. The author gratefully acknowledges comments on early versions of this paper by Ross Carter, Sir Kenneth Keith, Ben Hinchcliff , Ross Wilson and John Miller. 


\section{OWEN WOODHOUSE}

No account of the provenance of the 1967 Woodhouse Report or its contribution to New Zealand life can be divorced from the personal qualities of Owen Woodhouse himself. He was a complex, multifaceted human being, blessed with both penetrating insight and human empathy. His compassion for people was perhaps his most salient characteristic. The number and range of his friends and acquaintances both in New Zealand and overseas was astonishing.

Owen had the gift of friendship. He inspired loyalty and affection among those with whom he interacted and worked. He encountered many tough situations. He was a leader of determination with skills honed in the Second World War. He had the capacity to weld a disparate group into a team and produce high quality outcomes. It was my great good fortune to meet him when he and the Royal Commission investigating workers' compensation visited the University of Chicago Law School in 1966 where I was a student. It was the beginning of an enduring relationship that changed my life. ${ }^{1}$

Owen was a warm-hearted visionary blessed with judgment and wisdom. He believed those in distress should be helped and the well-being of each person should be of concern to all. He looked into the future and tried to see how it would be. These qualities were reflected not only in his judicial decisions and in his work as President of the Law Commission, but also in the reports on accident law he wrote both in New Zealand and Australia.

In all of this he carried his message through a unique prose style. Always spare, his prose had a limpid and crystalline quality. It was the result of painstaking drafting and redrafting. The Woodhouse Report in Australia went through nine drafts. He wrote these reports himself. They were powerful, elegant and persuasive. As the inaugural Woodhouse lecturer Sir Kenneth Keith said last year, clear thinking and clear writing were Owen's hallmark. ${ }^{2}$

\section{A The Common Law Origins of Accident Compensation}

New Zealand adopted the common law of England from the earliest days of European settlement. The common law of England and of New Zealand developed over time so that people who suffered personal injury by accident could recover damages. Assault and battery were always actionable in the courts, but the great tort of negligence developed over the latter half of the 19th century and expanded in the first half of the 20th. This opened up the possibility of significant awards of damages after a civil trial by jury.

1 For an account of the reform efforts in both Australia and New Zealand, see Geoffrey Palmer Compensation for Incapacity: A Study of Law and Social Change in New Zealand and Australia (Oxford University Press, Wellington, 1979).

2 Kenneth J Keith "Out of this nettle, danger, we pluck this flower, safety: Promoting safety through law, national and international, and by other means" (Sir Owen Woodhouse Memorial Lecture, University of Auckland, Auckland, 30 August 2017). 
To recover this, however, the plaintiff needed to demonstrate the injury resulted from the negligence of the defendant. This meant that many injured people could not succeed. There were three main defences available: contributory negligence on the part of the plaintiff; the notorious defence of common employment, where a worker who was injured by the fault of a fellow worker could not recover from the employer; and third, that the plaintiff voluntarily assumed the risk of sustaining injury. These defences were either modified or abolished by statute over time.

Nevertheless, the plight of the uncompensated victim at common law created a social burden that was too heavy to bear. ${ }^{3}$ Fault could be proved in only a minority of cases. Both England and New Zealand adopted workers' compensation statutes around the turn of the 20th century. The New Zealand statute provided modest periodic payments related to previous earnings (and hospital and medical expenses) to workers who could show their incapacitating injuries arose "out of and in the course of the employment". ${ }^{4}$ Workers' compensation included compensation for disease contracted from the employment. It also included some modest lump sum compensation payments for permanent loss of bodily function, although these did not match the pain and suffering damages that were available for a common law claim. There were also benefits for dependent survivors.

The liability created by both tort law and workers' compensation led to the need for insurance. The advent of the motor car quickly produced many accidents. Negligence on the highway became a significant source of common law claims. In 1928, New Zealand cured the problem of the impecunious defendant who was negligent but lacked the means to pay for a personal injury judgment by implementing compulsory liability insurance connected to the registration of vehicles. ${ }^{5}$ Insurance in relation to liability for work accidents was similarly mandated by statute.

Meanwhile the welfare state had been developing gradually notably with the passage of the OldAge Pensions Act in New Zealand in 1898. The Social Security Act 1938 provided a comprehensive system of flat rate payments by the state for people incapacitated through a variety of causes, including sickness and invalidity. A public health system was also established by that legislation.

These twin systems for personal injury proceeded alongside the welfare state without great public expression of discontent until the 1960s when a Royal Commission was established by the Government and reported in $1967 .{ }^{6}$ Yet change had been foreshadowed much earlier. Oliver Wendell Holmes observed in his famous book on the common law in 1881 that "[t]he state might conceivably

3 See Terence G Ison The Forensic Lottery: A Critique on Tort Liablity as a System of Personal Injury Compensation (Staples Press, London, 1967).

4 Workers' Compensation for Accidents Act 1900, s 6.

5 Motor-vehicles Insurance (Third-party Risks) Act 1928.

6 Compensation for Personal Injury in New Zealand: Report of the Royal Commission of Inquiry (Government Printer, December 1967) [Woodhouse Report]. 
make itself a mutual insurance company against accidents, and distribute the burden of its citizens' mishaps amongst all its members." ${ }^{7}$

\section{B The Woodhouse Report of 1967}

The three Royal Commissioners, chaired by Sir Owen Woodhouse, then a Judge of the Supreme Court, made bold, almost revolutionary recommendations. They were influenced by Sir William Beveridge's 1942 report in the United Kingdom. ${ }^{8}$ What began life as a legal reform became more far reaching with serious implications for income support. The resonances of the Report stretched far beyond private law into the principles governing public law provision for the welfare of people.

The Report was written in optimistic, even inspirational, language. ${ }^{9}$ It stated five simple social principles with great clarity. The community had a responsibility to protect all citizens from the burden of sudden individual losses, when their ability to contribute to the general welfare by their work was interrupted by physical incapacity. An injured person should receive compensation from a community financed scheme on the same uniform method of assessment regardless of the cause of injury. Emphasis should be on physical and vocational recovery and a real measure of compensation for their losses. Real compensation meant earnings related benefits would be paid up to high levels of income for the whole period of incapacity. There also needed to be recognition for permanent impairment. There should be no delays, inconsistency in assessment or waste in the administration of the scheme.

The Woodhouse Report was notable for the sustained attack it made on the weaknesses of the common law action for damages as a compensation system. The prime problem was that tort law failed to compensate large numbers of accident victims, but there were other weaknesses:

- $\quad$ waste was a feature of the system, due to large legal and administrative expenses so that much of the money raised never reached the injured;

- $\quad$ there were long delays in delivering benefits to those who secured them;

- personal blameworthiness was not the real rationale for the law because negligence law required individuals to meet the community average standard;

- $\quad$ as the Woodhouse Report put it: "[r]eprehensible conduct can be followed by feather blows while a moment's inadvertence could call down the heavens"; ${ }^{10}$

- $\quad$ liability insurance had blunted or removed the deterrent effect of tort law;

7 Oliver Wendell Holmes The Common Law (M DeWolfe Howe (ed), Little, Brown and Company, Boston, 1963) at 77. This was not a change Holmes favoured.

8 Social Insurance and Allied Services: Report by Sir William Beveridge (HMSO, Cmd 6404, 1942).

$9 \quad$ Woodhouse Report, above n 6, at [484].

10 At [85]. 
- $\quad$ an assessment of damages in one lump sum involved guesswork and speculation and tended to overcompensate less serious injuries;

- the process of adjudication was a lottery and impeded the rehabilitation of injured people, and there were strong incentives to maximise misery; and

- $\quad$ accident prevention was impeded by the system.

The Royal Commission's attack on the utility of the common law action was fundamental to the success of the proposals. Unless that action was removed there could be no comprehensive scheme. Five principles underpinned the Commission's recommendations: community responsibility, comprehensive entitlement, complete rehabilitation, real compensation and administrative efficiency. In reality, however, many of the detailed recommendations were altered in the political processes that followed the 1967 report. $^{11}$

All of tort law was to be swept away for personal injury. Everyone who was injured by accident - whether it was at work, on the road, at play or anywhere else - would be compensated. And virtually no new money would be needed. It would all be paid for out of the funds that were compulsorily exacted to pay for the tort system and the workers' compensation system. That was because these systems not only denied many people adequate compensation, but they cost a lot to run - as much as 40 per cent of the total money collected by statute to fund the schemes. Much of the money was chewed up by insurance companies, the costs of investigations into fault and by the costs of litigation. The basic thrust of the Woodhouse reform was to collapse all the existing programmes and replace them with one comprehensive co-ordinated system of earnings-related compensation for all incapacity resulting from injury. The scheme provided twenty-four hour protection for all accident victims, without the need to exact new taxes to pay for it.

The Woodhouse Report contained a radical programme and the National Government took time to study it. An official commentary exploring the feasibility of the proposals, their costings and suggesting some possible changes, gave the scheme a vote of confidence. ${ }^{12}$ It was then examined at length by a parliamentary Select Committee. In the end the scheme was adopted but with a substantial number of changes.

\section{What Happened to the Woodhouse Report}

The scheme from the Royal Commission looked most attractive to the public. But adopting it took time, as it involved depriving insurance companies of a significant portion of their business and

11 Palmer, above n 1. See also Geoffrey Palmer "New Zealand's Accident Compensation Scheme Twenty Years On" (1994) 44 UTLJ 223; and Geoffrey Palmer "The Design of Compensation Systems: Tort Principles Rule, OK?" (1995) 29 Val UL Rev 1115.

12 Personal Injury: A Commentary on the Report of the Royal Commission of Inquiry Into Compensation for Personal Injury in New Zealand (Government Printer, October 1969). 
transferring those funds to the state. This feature made some in the ruling National Government nervous.

The scheme was finally adopted and became operative on 1 April 1974. Significant changes to the Royal Commission's recommendations were made in the political process and some of those decisions have not produced the best results. The 1972 Act did not cover non-earners as originally passed, but when a Labour Government was elected in late 1972, the coverage was extended to include them. The Act, however, was not redone so the logic of comprehensive coverage was not reflected in the legislation. The administrative arrangements have changed over the years. Changes in what is covered by the scheme have been adjusted from time to time. While the Royal Commission recommended a "pay-as-you-go" method of financing the scheme, there have been significant efforts to accumulate funds. A large capital fund has been built up and is invested, so the scheme looks in part like an actuarially-based private insurance scheme. At one point in the 1990s, significant parts of the scheme were privatised, but that was later reversed.

Altogether, only about half of the major policy recommendations in the Woodhouse Report were implemented. Key provisions were rejected. This makes it difficult to judge how the Woodhouse reform model would have worked had it been enacted more substantially in the terms that it recommended. ${ }^{13}$ The Woodhouse Report has not been tried yet. The major policy issues upon which the Woodhouse approach did not prevail included the administrative arrangements, the methods of financing, the compensation payments themselves, particularly opposition to lump sums and the design of the systems for determining disputes about eligibility, and the causes of, and the degree of, incapacity. Had the Report been followed, it would have been easier to integrate the scheme into the rest of the income support system.

Another matter that is relevant in light of recent experience flows from the manner in which the Royal Commission envisaged claims being dealt with. At paragraph 309(b) of the Report the Commission said: ${ }^{14}$

Informal and simple procedure should be the key to all proceedings within the jurisdiction of the Board.

Applications should not be made to depend upon any formal type of claim, adversary techniques should not be used, and a drift to legalism avoided.

That aim has clearly not been achieved. Indeed, there have been constant difficulties about how to resolve disputed cases and the District Court was brought in to decide cases some years ago. More than 45 years after the enactment of this scheme, one thing has remained constant. There has been no political appetite on any side of politics to return to the common law action for damages of the past.

13 Geoffrey Palmer "What Happened to the Woodhouse Report?" [1981] NZLJ 561.

14 Woodhouse Report, above n 6, at [309(b)] (footnotes omitted). 
That consensus is founded on the clear evidence that, had the previous system been retained, it would be costing significantly more than accident compensation.

The Accident Compensation Corporation (ACC) has developed into a large and significant public organisation with a big footprint on New Zealand life. The 2017 Annual Report stated that it had 3,500 staff. It received 1.95 million new claims. It paid 85.8 per cent of total expenditure either directly to claimants or for services for them. It has an investment portfolio of $\$ 37,300,000,000$. That year it reported improved satisfaction levels from claimants after several years of lower ratings. In 2017, 30.6 per cent of the population received compensation or rehabilitation services from the Corporation. The average time to commence weekly compensation payments was seven days. While formal reviews numbered only 2.7 per cent of entitlement claims, 81.7 per cent of them were upheld. The average time for resolution of claims with reviews was 94.8 days. Of the claimants, 68.4 per cent had returned to work within 10 weeks and 93.1 per cent had returned to work within nine months. Levies exacted for the scheme amounted to 1.6 per cent of gross domestic product. ${ }^{15}$ In September 2018 ACC announced it was "doubling its investment in a huge business transformation programme to $\$ 669$ million, forecasting that it would make its staff an extra 10 per cent more productive". ${ }^{16}$

\section{Finance, Delivery and Administration}

An important issue in the financing of the scheme has been the debate between the relative merits of "pay-as-you-go" compared with a fully funded scheme. Private insurance schemes have to be fully funded in order to ensure that the insurance company can meet the costs as the claims run off. This can take many years, especially in a scheme that pays benefits for a long time, for example in the case of those seriously injured and incapacitated when young. Actuaries can assess these risks, based on a combination of empirical data and assumptions, and arrive at assessments of the funds required in order to meet the future payments. Governments do not have to do this. They can increase or reduce the levies as things change. Obviously it is prudent to have substantial reserves in case of catastrophe so that collecting more than is needed for a period is wise - this is called a partially funded scheme.

Clearly, at the beginning there are only a few people who are permanently incapacitated and it takes 15 or 20 years for the scheme to reach its full costs or "plateaus". Therefore, it is wise to cost the whole thing on a "plateau" basis, even though during the first year only those injured during the first year would be paid. Thus, substantial funds are available for investment.

In discussing this question, the Royal Commission said it was necessary to take in more than was needed in the first few years. But it observed at paragraph 479:17

15 Accident Compensation Corporation Investing in New Zealanders: Annual Report 2017 (September, 2017).

16 Tom Pullar-Strecker "ACC 'doubles down' with $\$ 669 \mathrm{~m}$ transformation project" The Dominion Post (Wellington, 5 September 2018) at 23.

17 Woodhouse Report, above n 6, at [479]. 
As the scheme will be a Government scheme of social insurance it must in the final resort recieve the backing of the State. It is for this reason that a formal system of funding cannot be regarded as essential to the stability of the scheme.

The extraordinary gyrations over the scheme's funding over the years indicate misunderstanding as to its real nature. Changes in policy in New Zealand at various times have caused the costs of the scheme to become items of public controversy when a more sophisticated understanding and better policies could have avoided such problems.

Employers objected in the 1980s to the levies they were paying because reserves were being accumulated by the scheme. They had also sought and obtained variable levies rather than the flat rate levies recommended by the Woodhouse Report. An amendment Act in 1982 removed the requirement that levies should be set on a fully funded basis, allowing future levies to be set on a "pay-as-you-go" basis. This produced a short-term reduction in levies and a subsequent blowout in the levy rates and a running down of the reserves. When the levies had to be increased again as a result there was further criticism. ${ }^{18}$ The result has been that these levies are not regarded so much as a tax as an insurance premium in which the employers and self-employed have a vital interest. They see it as an opportunity where they can minimise their costs, for example by reclassifying the risk category into which their staff fall. ${ }^{19}$

Related to these efforts by employers were the efforts to privatise the scheme. The Accident Rehabilitation and Compensation Insurance Act 1992 reduced the benefits offered by the scheme. The changes included the abolition of lump sum compensation and payment for partial loss, the introduction of insurance language into the Act, limits on compensation for medical misadventure, limits on rehabilitation payments and work capacity testing. Most of these changes did not endure.

Then there was the short-lived experiment to allow private insurance companies to write insurance for the earners' scheme that was passed in 1998 and repealed by the new Labour Government that came into office in 1999. The scheme was changed in 1998 to provide for full funding, a necessary prelude to the introduction of competition from insurance companies. But when Labour repealed the privatisation it retained full funding. This seems to have been because of the decision to consolidate the Corporation's financial performance onto the Crown's balance sheet. With the accrual accounting required by the Public Finance Act 1989, this means that the future costs of the scheme and those seriously injured who will be on it for many years are reflected in the government accounts. The logic

18 Don Rennie "Administering Accident Compensation in the 1980s" (2003) 34 VUWLR 329 at 333.

19 Over the years there has been significant debate in the academic literature as to whether internalisation of accident costs can be achieved by risk-related levies, thereby deterring accidents. See Guido Calabresi The Costs of Accidents: A Legal and Economic Analysis (New Haven, Yale University Press, 1970); and Don Dewees, David Duff and Michael Trebilcock Exploring the Domain of Accident Law: Taking the Facts Seriously (Oxford University Press, New York, 1996). But to design a practical scheme that effectively achieves this goal seems impossible. 
of this approach does not square with the manner in which the future costs for education and health are dealt with in the public accounts.

Social insurance is quite a different concept from private insurance. The Woodhouse scheme was about the social goals and social purposes of a compassionate and just society. Some of the attacks on the scheme by some economists have been full of assertion about inefficiency, moral hazard and policy failure, objections that seem to be based more on neo-liberal ideology than on sound economics. Likewise, a proper understanding of the purpose of New Zealand's scheme suggests that privatisation is no more appropriate for accident compensation than for benefits under the Social Security Act 1964.

There have been many statutory reconstructions, administrative changes and variations since the scheme began in 1973. The Woodhouse Report recommended the scheme be brought to life by an independent three-person Commission, with its own staff. This recommendation was heavily influenced by the organisation of the then Ontario Workmen's Compensation Board. But since the new scheme involved a partial merger with some aspects of the then social security system, it should operate under the general responsibility of the Minister of Social Security (now the Ministry of Social Development) and be attached to that department for administrative purposes. That never happened and it remained with the Department of Labour, that was much later absorbed into the Ministry of Business, Innovation and Employment.

The changes in the 1982 Act, however, set a pattern that essentially survives to this day. The administrative change was to abolish the Accident Compensation Commission and to substitute for it a statutory corporation presided over by a board. Section 267 of the Accident Compensation Act 2001 provides for a board of not more than eight members appointed by the Minister under the Crown Entities Act 2004. While there is a Minister for ACC, ministerial responsibility is attenuated by virtue of the Corporation's legal and administrative form. ${ }^{20}$

The purpose of the 1982 policy appears to have been to try to insert a degree of stakeholder participation into the policy settings. It was also aimed at bringing a more business like set of management processes to the bureaucracy. It became in 1982 a rather different organisation. In time, practices developed that permitted a measure of privatisation subsequently enacted by the National Government in the late 1990s.

Neither the independent Accident Compensation Commission of three Commissioners in the first instance, nor the later statutory corporation, were organised as part of the core state services. Thus, the accident compensation system became something of a policy orphan within government. What is now the Ministry of Business, Innovation and Employment, has responsibility for policy advice. A search of its website does not disclose great activity or even much information concerning its policy

20 Geoffrey Palmer "'The Nineteen-Seventies': Summary for Presentation to the Accident Compensation Symposium" (2003) 34 VUWLR 239. 
function. ${ }^{21}$ Accident compensation is listed as one of the Ministry's regulatory systems for which it is responsible, but is it really a regulatory system? The Ministry does consult on new regulations to be made under the statute. In practice, policy has often been developed by the Commission and later the Corporation itself and then submitted to the Ministry. The policy-generating capacity of the ACC itself has turned out to be somewhat haphazard and unsatisfactory. The Treasury has always taken a strong interest in the scheme because of the quantity of public funds involved in it. Uneasy tensions inhabit the shared interests in the scheme of various parts of the government and these are not easily resolved.

It is doubtful that the Ministry of Business, Innovation and Employment has been an effective adviser. It does not seem to have been able to provide advice to avoid the various policy mistakes that have occurred, although perhaps they were the work of ministers. The policy advice problem is structural and will not be cured until the structure is altered. Further, the Corporation was left aside from deliberations within the core government departments for long periods of time. The result was that there was insufficient integration of policy advice within the workings of central government or the relationship of the scheme to the other programmes for income support.

The administrative problems that have been encountered by the accident compensation scheme over the years could have been avoided to a substantial extent if the original policy prescription had been followed. The corporate form of organisation has engendered substantial public resistance at various times since it suggests a business for profit rather than social insurance. It is an outlier within the government system. A number of controversies have beset it in recent times and there has been a recent independent inquiry over claim handling. ${ }^{22}$ Over time efforts have been made to turn the scheme into something that it is not and was never intended to be. Having a board has not in my view added value. A department of state would never have behaved in the way that the Corporation has done in respect to recent controversies. It would be better to hand the administration over to a department of state operating on the conventional principles of ministerial responsibility. ${ }^{23}$

21 Ministry of Business, Innovation and Employment "Search Results for 'Accident Compensation'" $<$ www.mbie.govt.nz/search $>$.

22 Miriam R Dean "Independent Review of the Acclaim Otago (Inc) July 2015 Report into Accident Compensation Dispute Resolution Processes" (Ministry of Business, Innovation and Employment, May 2016) [Dean Inquiry Report]. In July 2018 a careful three-part piece of investigative journalism drew attention to a number of issues: Cate Broughton "When ACC says No" The Dominion Post (Wellington, 16 July 2018) at 14; "Battle lines in the fight for ACC" The Dominion Post (Wellington, 18 July 2018) at 16-17; "ACC 'can't keep going the way it is"' The Dominion Post (Wellington, 20 July 2018); and Don Rennie "ACC and the Woodhouse Principles: Comprehensive Entitlement" (2018) 919 Lawtalk 19.

23 On the administrative structures erected see John R Martin "Establishment of the Accident Compensation Commission 1973: Administrative Challenges" (2003) 34 VUWLR 249. 


\section{E Accident Prevention and Rehabilitation}

The Royal Commission report stressed the primacy of accident prevention and rehabilitation of accident victims as having priority over the issue of payment of compensation. That aim never seems to have been fully achieved. New Zealand never received what was envisaged: a "unified and comprehensive scheme of accident prevention, rehabilitation, and compensation". ${ }^{24}$ There has been more emphasis and political attention upon paying the compensation than there has been on either accident prevention or rehabilitation, although significant amounts of ACC funds are spent on rehabilitation. What has prevented this in part was the overlapping responsibilities of various government departments. The ACC system makes a large contribution to health spending but the carriage of the health system is with the Ministry of Health. ACC is not the prime mover in either the rehabilitation arena or in accident prevention.

Rehabilitation by ACC has been the subject of critical and knowledgeable commentary by Don Rennie, the convenor of the New Zealand Law Society's Accident Compensation Committee. He writes: 25

The ACC should be a world leader in the rehabilitation of injured people covered by the Act, but for many years it appears that getting claimants "off the system" has taken priority over ensuring that a claimant's health, independence and participation for [(despite)] all the ongoing consequences of the injury...The ACC cannot claim it has an outstanding or even a successful record in achieving what the Woodhouse Report recommended in providing all accident victims with complete rehabilitation.

It was thought that comprehensive injury statistics could be generated from the new scheme and indepth analysis applied to the statistics, thus providing new opportunities for preventing serious accidents. The ACC website does have data on claims statistics over the past five years. ${ }^{26}$ But this has taken too long to arrive. The Statistics New Zealand website concentrates primarily on work injury statistics and one is left with the impression that the new data that should have been unearthed by the scheme has not been adequately captured or analysed. ${ }^{27}$ It should be noted the light-handed regulatory model in New Zealand in relation to health and safety at work failed, as found by an inquiry into a coal mine accident in which 29 men lost their lives. ${ }^{28}$ This and other failings led to the repeal of the Health and Safety at Work Act 1992 and the enactment of Health and Safety and Work Act 2015 which is anything but light-handed.

24 Woodhouse Report, above n 6, at [488(1)].

25 Don Rennie "ACC and the Woodhouse Principles: Complete Rehabilitation" (2018) 920 Lawtalk 40.

26 Accident Compensation Corporation "Statistics on our claims" <www.acc.co.nz>.

27 Statistics New Zealand "Injuries" < www.stats.govt.nz>

28 Graham Panckhurst, Stewart Bell and David Henry Royal Commission on the Pike River Coal Mine Tragedy: Volume 1 + Overview (October 2012) at 32. 
Changing the administration of ACC needs to be considered. It can be strongly argued that if the accident compensation system was administered through a department of state, this would ensure that the policy-making for the scheme would be better considered and better aligned with other income support programmes designed to alleviate poverty.

\section{F A Return to Legalism?}

Over the years the accident compensation legislation has become longer and more complex. It is less generous than when it began and more restrictive. It now covers 338 pages of the statute book. The first enactment was the Accident Compensation Act 1972, amended to cover non-earners in 1973. A new Act with the same name followed in 1982. This was replaced by the Accident Rehabilitation and Compensation Insurance Act 1992, then briefly the Accident Insurance Act 1998, and the present Accident Compensation Act 2001. This last Act began life as the Injury Prevention, Rehabilitation and Compensation Act but was renamed by a 2010 amendment. And there were also many amendments of those Acts made in the intervening years. These Acts bear the marks of ideological battles as their titles indicate.

The lines of demarcation that are drawn in the current legislation are technical, difficult and sometimes unfair. The problems facing claimants are formidable. The obstacles have been deliberately increased over the years. If claimants read the statute they would have little chance of understanding it. The legislation seems unfit for the social purpose for which it is designed. What has developed is not what the designers envisaged. Here is what the Chief Justice said about the Act in a 2012 Supreme Court decision: ${ }^{29}$

The Injury Prevention, Rehabilitation, and Compensation Act 2001 provides cover on the basis of linedrawing which reflects policy choices. Such line-drawing has resulted in legislation which is technical.

Approaches taken to the interpretation of provisions under earlier accident compensation legislation need to be treated with some caution in considering the current legislation. Nor is this easy legislation to follow.

It contains much cross-referencing, repetition, and circularity in expression.

Applicants dissatisfied with the Corporation's decision can undertake a review before an independent reviewer, who conducts a hearing. This is organised by a company contracted to the ACC, an arrangement that seems anomalous for a responsibility of the state. ${ }^{30}$ Either side can then appeal to the District Court. From there, there can be an appeal on a point of law to the High Court, and from there to the Court of Appeal with leave. The decision of that court is final, meaning cases cannot be taken to the Supreme Court. ${ }^{31}$ A search of the Ministry of Justice's "Judicial Decisions

29 Allenby v H [2012] NZSC 33, [2012] 3 NZLR 425 at [7] per Elias CJ.

30 The review process is organised and run by a company, FairWay Resolution Ltd.

31 Accident Compensation Act 2001, ss 134-163 deal with dispute determination. 
Online" records shows that there were 437 accident compensation cases in the High Court and Court Appeal between 2003 and February 2018. ${ }^{32}$ There probably have been thousands in the District Court.

This was a scheme to do away with the need for lawyers when claiming compensation for personal injury. Now the legislation is so intricate that lawyers are often needed. Constant legislative fiddling with the scheme has produced injustices. Eligibility depends upon which of the statutes the injured person may be subject to and sorting out the transitional problems as between the various Acts passed over the years is something of a legal tangle. ACC has become highly legalistic, and this has created unfairness. The way in which medical evidence is used to deny claims has attracted much vocal opposition in the community. An extensive research project from the Faculty of Law at the University of Otago found that the ACC legislation was being administered unfairly in some cases. The research concludes: ${ }^{33}$

Over time, causation has come to be applied in a narrow, technical, legalistic way. Because of this, any dispute with ACC involves legal advice, legal representation, and complex medical evidence. Causation is inherently arguable and difficult to assess.

As the Otago research finds, the approach is redolent of how the subject was approached in the old tort system. Efforts have been made to improve the dispute settlement system since 2015 and make it fairer. At the time of writing, nothing concrete has eventuated, although efforts are continuing. ${ }^{34}$

\section{G The Future Pattern of Income Support and ACC}

The New Zealand accident compensation scheme has been through many iterations since it was first passed by Parliament in 1972. One constant feature has been the discrimination in public programmes that relieve the consequences of some misfortunes and disabilities but not others. One lottery replaced another. The person laid low by cancer, a heart attack or stroke is treated much less generously than the person who suffers an accidental injury resulting in the same incapacity. The first group is easily impoverished by the drop in income compared with the person receiving compensation under ACC. As Professors Walter Blum and Harry Kalven Jr, whom Owen visited at Chicago, wrote

32 Ministry of Justice "Judicial Decisions Online" < www.justice.govt.nz>.

33 Warren Forster, Tom Barraclough and Tiho Mijatov Solving the Problem: Causation, transparency and access to justice in New Zealand's personal injury system (University of Otago Faculty of Law Legal Issues Centre, 22 May 2017) at 1. For the legal issues see also Ben Thompson Accident Compensation Act: Key Sections and Commentary (LexisNexis, Wellington, 2014); and Stephen Todd (ed) The Law of Torts in New Zealand (7th ed, Thomson Reuters, Wellington, 2016) chs 2 and 3.

34 The Dean Inquiry Report published in 2016, above n 22, found there were inefficiencies in the dispute resolution system. There were at least four significant problems: being heard, access to the law, access to evidence and access to representation. While efforts are being made to improve the system and the ACC is working on it, nothing of substance had eventuated at the time of writing. See Accident Compensation Corporation "Update to Minister on implementing Dean Review recommendations" (26 February 2018) $<$ www.acc.co.nz>. 
in 1965 concerning the then efforts to provide better redress for the victims of automobile accidents in the United States: ${ }^{35}$

Private law cannot borrow goals from public law fields without accepting the obligation to make a proper public law analysis. In the case of automobile compensation plans, such an analysis shows that the special problem cannot be solved adequately without solving the larger problem.

The larger problem was poverty and while accident compensation has reduced poverty in New Zealand compared with what went before it, it certainly has not eliminated it.

The explanation for the discrimination in New Zealand revolves around the shortage of available money and changing political priorities. ${ }^{36}$ First, in 1975 there was an election campaign in which superannuation for people over 60 was the single most important issue. This development effectively removed the issue of financing an extension of the accident compensation principles to sickness and invalidity off the agenda for many years. Expenditure on the aged as a result went up 57.6 per cent, although this reduced later when the age of eligibility for superannuation was increased to the age of 65. The second reason for failure to act, although less important than the first, was the fact that the 1972 Royal Commission of Inquiry into Social Security in New Zealand had not recommended anything along the lines of the 1967 Woodhouse Report. ${ }^{37}$ An effort was made by a later Royal Commission to deal with the issues but with no legislative result. ${ }^{38}$ The Fourth Labour Government introduced the Rehabilitation and Incapacity Bill 1990, based on a Law Commission report when Sir Owen Woodhouse was its President. ${ }^{39}$ The Bill was designed to extend the scheme to sickness, but it was not proceeded with by the incoming National Government.

The Woodhouse Report in New Zealand, and the later inquiry Sir Owen Woodhouse chaired for the Australian Government that reported in 1974, were intended to overtake the flat rate benefit system and apply to all forms of income maintenance for incapacity, including those resulting from sickness and congenital incapacity. ${ }^{40}$ For a number of reasons the aim of integration has never been achieved

35 Walter J Blum and Harry Kalven Jr Public Law Perspectives on a Private Law Problem: Auto Compensation Plans (Little, Brown and Company, Boston, 1965) at 85.

36 For background to the policy developments see the essays in Geoffrey Palmer (ed) The Welfare State Today - Social Welfare Policy in New Zealand in the Seventies (Fourth Estate Books, Wellington, 1977).

37 Social Security in New Zealand: Report of the Royal Commission of Inquiry (Government Printer, 1972).

38 The April Report Volume II: Future Directions - Report of the Royal Commission on Social Policy (Government Printer, April 1988) at 757.

39 See Law Commission Personal Injury: Prevention and Recovery - Report on the Accident Compensation Scheme (NZLC R4, 1988).

40 Compensation and Rehabilitation in Australia: Report of the National Committee of Inquiry (Australian Government Publishing Service, 1974). 
but the issues need to be addressed. Serious social inequalities stem from the preferential treatment enjoyed by accident victims not only in income support but also in the rehabilitation available.

Long standing complaints about the sad state of the law in the Social Security Act 1964 led to a significant project to rewrite it that lasted for years and spanned two governments. Judges had commented adversely upon the Act. In 2014, I stated that the 1964 Act "has been a convoluted mess for many years, despite its vital importance to many thousands of people". ${ }^{41}$ It was a top candidate for the booby prize as the worst statute on the New Zealand books. The Social Security Legislation Rewrite Bill began for a second time under the National Government and was introduced to Parliament in 2016. The Ardern Government amended the Bill, although National's Bill had been substantially amended in the Committee of the Whole House. ${ }^{42}$

In the first reading debate on 10 May 2016 of the Social Security Legislation Rewrite Bill, the Hon Anne Tolley said: 43

This Bill rewrites the Social Security Act 1964. After more than 50 years the Social Security Act is long overdue for a rewrite. When it was first passed it had 135 sections. It has since grown to 523 sections and, of those, only four remain unchanged, 214 sections have been repealed, and most sections have been amended multiple times - in one case, 286 times. Altogether, that makes for a very disjointed and confusing Act ...

An earlier amendment Act, the Social Security (Benefit Categories and Work Focus) Amendment Act 2013 s 62 and pt 1 of sch 2, amended the 1964 Act to reorganise headings and "make clearer [the]

41 Geoffrey Palmer "Law-Making in New Zealand: Is There A Better Way?" (2014) 22 Wai L Rev 1 at 4.

42 (8 May 2018) 729 NZPD (Social Security Legislation Rewrite Bill 2016 - Second Reading, Hon Carmel Sepuloni); and Supplementary Order Paper 2018 (25) Social Security Rewrite Bill 2018 (122-1) summarised the changes as: (1) "[r]emoving some identified changes to effect of current law"; (2) "[a]dding some minor changes or clarifications to effect of current law"; (3) "[m]aking some minor drafting corrections or improvements"; and (4) "[u]pdating since Bill reported on 14 September 2016 from Social Services Committee".

43 (10 May 2016) 713 NZPD 10897. The 2016 Rewrite Bill was also the subject of a report under s 7 of the New Zealand Bill of Rights Act 1990 - as noted by Hon Anne Tolley in her first reading speech: "[t]he AttorneyGeneral's report on this bill identifies a group of provisions that favour people who are totally blind and finds that it is inconsistent with the New Zealand Bill of Rights Act. These provisions are some of the most longstanding social security measures in New Zealand, dating back to 1924. They help a small group of disadvantaged people: those who are totally blind. These longstanding measures are re-enacted unchanged in the bill as part of the policy-neutral approach. They will remain lawful under the Act." Notably the New Zealand Court of Appeal in 2008 said any (assumed) prohibited discrimination on the ground of disability (assuming disability could include "cause of disability", such as multiple sclerosis): "[t]he costs of illness were to continue to be provided by the state's health system and/or private insurance. That policy choice, albeit it may give rise to anomalies of the sort raised by the applicant, constitutes a justified limit in terms of [the New Zealand Bill of Rights Act 1990] s 5." See Trevethick v Ministry of Health [2009] NZAR 18 (CA) at [18] per Ellen France J for the Court (Chambers, Arnold and Ellen France JJ). 
principal Act's structure" by "retrofitting" or overlaying a series of Part and other headings. This was needed to signal when the provisions of the 1964 Act as amended switched from one topic to another topic, but it also made clear that the 1964 Act as amended meandered from one topic to another and intermixed substantive and administrative provisions - it no longer had a coherent overall structure or scheme. ${ }^{44}$

The result of this project was a massive Bill of 501 pages (including revision-tracked amendments) considered by the Committee of the Whole House, and split into, and reported back as, three Bills - the Social Security Act 2018 (450 pages), the Residential Care and Disability Support Services Act 2018 (46 pages) and the Artificial Limb Service Act 2018 (9 pages). The Bills were enacted in September 2018. The Social Security Act 1964 remained in force until 26 November 2018 and provided the legal basis for most of those benefits.

The Rewrite Bill as introduced was intended to be policy neutral but the Labour Party and the Greens could not support it because it contained a number of new measures that they thought were not neutral. ${ }^{45}$ The Ardern Government took up the measure that was on the Order Paper and changed it significantly. The Rewrite Bill as enacted can be seen as a stocktake and platform for further change. This is especially because of its "policy neutral" approach and because it is not a reforming measure for any political party. Its reorganisation makes plainer the current landscape and structure of the law. This by itself helps make clear the issues and problems of the current law and what is needed to make coherent changes, for example, to introduce a new entitlement such as the Winter Energy Payment. ${ }^{46}$ It may be remarked, however that all is not well in a system that requires a policy neutral rewrite in order to find out where we are so that more significant changes can be made.

Hon Carmel Sepuloni and Jan Logie signalled on 28 May 2018 that further work is to be done on reforms: areas that the Welfare Expert Advisory Group has been asked to focus on. These range from issues from considering the overall purpose of the system, through to specific recommendations on the current obligations and sanctions regime. ${ }^{47}$ That there is more work to do is from my point of

44 Social Security (Benefit Categories and Work Focus) Amendment Act 2013, s 62.

45 Political parties' positions as the Bill progressed are observable in part from the Hansard related to the Rewrite Bill: (10 May 2016) 713 NZPD 10897; (8 May 2018) 729 NZPD (Social Security Legislation Rewrite Bill Second Reading); (15 May 2018) 729 NZPD (Social Security Legislation Rewrite Bill - In Committee); (23 May 2018) 729 NZPD (Social Security Legislation Rewrite Bill - In Committee); (24 May 2018) 729 NZPD (Social Security Legislation Rewrite Bill - In Committee); (4 July 2018) 729 NZPD (Social Security Legislation Rewrite Bill - In Committee); and (24 July 2018) 729 NZPD (Social Security Legislation Rewrite Bill - In Committee). See also Social Services Committee Social Security Legislation Rewrite Bill: As reported from the Social Services Committee - Commentary (14 September 2016).

46 Work and Income "Winter Energy Payment" <www.workandincome.govt.nz>.

47 Hon Carmel Sepuloni "Expert group established to provide independent advice on welfare system improvements" (press release, 28 May 2018); and Stacey Kirk "Government appoints 11-strong advisory panel to advisory panel to overhaul welfare system" (28 May 2018) Stuff <www.stuff.co.nz>. See also Sarah 
view an understatement. There appears to be no current move to integrate accident compensation into the rest of the welfare system. But there are other issues too. Some benefits are inflation or wage adjusted and some are not. And where they are adjusted there is not a consistent pattern, especially comparing superannuation adjustments with social security benefits. Further, more onerous obligations are placed on some claimants than upon others. There remains a lack of policy consistency even with the rewritten Act. It must be said, however, that the rewrite is a leap forward in terms of clarity, accessibility and for the rule of law.

Issues about the fairness of the method of handling disputes in this area tends to mirror what I have said about the ACC dispute settlement mechanism. The new Social Security Act 2018 Part 7 contains provisions on "[r]eviews and appeals". The Part has a Guide. But the system is quite complex and more procedural material will be in regulations. Appeals to the High Court continue to be on a question of law only. It can be challenging to test the Ministry of Social Development's decisions, even successfully. A recent High Court decision from Justice Paul Davison stands as a powerful example. ${ }^{48}$ The dispute appears to have lasted seven years so far.

Ms F is a solo parent with two dependent children. Between 2005 and 2010 she received the Domestic Purposes Benefit as well as other forms of assistance under the Social Security Act 1964. In 2010 following a tip-off from Ms F's ex-partner, the Ministry of Social Development commenced an investigation into her financial circumstances and reviewed her benefit entitlements. It found she had received income from various additional sources and as a consequence had been paid more than she was entitled to in the form of social security assistance. The Ministry sought to recover $\$ 109,852$ in overpayments. She appealed the decision to the Benefits Review Committee, thence to the Social Security Appeal Authority. Both sides appealed from there by way of case stated on points of law to the High Court.

The Judge decided that the Authority had erred in its interpretation as to what constitutes income under the definition contained in the Social Security Act, although it had got some of it right. A loan from her mother was not income, if it was a loan, since it had to be paid back. Her credit card expenditure was not income either. But money from other unknown sources was income. Her spending from bank loans borrowed on the security of her home to meet living expenses was not income. So Ms F prevailed in the most important issues in the case but it had to be sent back to the Authority to deal with the facts concerning the nature of the advance from her mother as to whether it was loan or gift.

Several points arise here. First, it seems wrong that in this class of case that the senior courts are not more involved. Important points of statutory interpretation should not be finally decided by

Robson "Govt to scrap benefit cuts for mums who don't name father" (14 November 2017) Radio New Zealand <www.radionz.co.nz>.

48 F v Ministry of Social Development [2018] NZHC 1607, [2018] 3 NZLR 260. 
tribunals with appeals possible only on points of law. In the case above, the High Court could not make findings of fact or even effectively review them. Second, it seems wrong that such a matter should last so long, and be so complex. Third, it is wrong in principle that matters of such significance to so many people cannot, except by exceptional procedural manoeuvring, be decided by the Supreme Court. The same is true for ACC cases. Such restrictions are not compatible with a proper understanding of the rule of law in a democracy.

It is hard to resist the conclusion that income support programmes in New Zealand have developed in a haphazard and unprincipled way that is both confusing and unnecessarily complicated. Earningsrelated benefits for accident victims with some lump sum compensation for non-economic loss is provided under ACC. Flat rate income tested benefits are provided for those who are sick or are otherwise incapacitated. Tax rebates are also available for some people and there exist a wide variety of special benefits.

A generous and nearly universal scheme for those over the age of 65 is provided regardless of assets or income by the New Zealand Superannuation and Retirement Income Act 2001. The Act includes the New Zealand Superannuation fund designed to provide resources to meet the present and future costs of superannuation. Nevertheless, substantial evidence exists that future demographic pressures will render the scheme unsustainable. The KiwiSaver Act 2006 provides for a voluntary retirement savings scheme to which both employees and employers contribute.

Taken as a whole, an objective observer might be pardoned for thinking that the entire income support system in New Zealand amounts to a new form of feudalism where different classes of people are subject to unequal distinctions lacking in principle. ${ }^{49}$ The state provides for people but with different hoops to be jumped through with different results in the amount of help available. The dependence upon the state is strong so it is important that the law of governing these matters is as free from discretion as possible, is clearly stated and is fair.

The Work and Income website provides links to 62 different benefits and payments that people can apply for. ${ }^{50}$ The variety is quite remarkable. The Inland Revenue Department (IRD) has done work on the five social policies it administers - Working for Families, child support, student loan repayments and KiwiSaver. The 2017 IRD consultation paper "Making Tax Simpler: Better Administration of Social Policy" shows the challenges involved in delivering social policies within a tax administration programme and the need for improvements. The Working for Families programme provides a variety of tax credits for families with children up into generous income levels, depending

49 Charles A Reich "The New Property" (1964) 73 Yale LJ 733 at 770. The law of real property, particularly estates in land, is based to a substantial extent on concepts that flow from English feudalism after the Norman Conquest.

50 Work and Income "A-Z benefits and payments"< www.workandincome.govt.nz> 
on the number of children. ${ }^{51}$ Another complication flows from the provisions of the Veterans' Support Act 2014, recently reviewed. ${ }^{52}$

Considered as a whole, the totality of the income support system could be seen as an incomplete negative income tax scheme or looked at another way, a guaranteed minimum income. Such an approach does not look out of the question when one examines the disparate New Zealand support programmes as whole. We may be moving in that direction. Gail Duncan has stated: ${ }^{33}$

The income of a beneficiary needs to be reframed as being an income the recipient is entitled to as an

economic unit in New Zealand society, rather than being a burden or inconvenience to the taxpayer.

The need to produce some coherence out of these disparate programmes seems to me to be pressing. The present pattern is the antithesis of joined-up government. It ought not to be beyond us to review the whole disjointed picture and provide a unified, integrated scheme for income support for all forms of disability and retirement based on carefully articulated principles. Entitlements needs to be clearly defined in the legislation that people can understand, and as free from discretion as possible. Dispute settlement needs to be simple and cheap, freed from legalism as far as possible. Such a step would help us to deal with the social problems resulting from poverty that is such a contemporary challenge.

Any re-engineering of the New Zealand version of the welfare state will be politically difficult. At present, matters are both confused and complex. We face a number of foreseeable challenges. A new simplicity based on fairness is called for. Increased life expectancy poses serious issues for universal retirement income on the current basis. The overall affordability issue will always be present given the high cost of all transfer payments. What can be afforded and how that ranks in terms of political priorities are issues that will never go away. The future of work, and the degree to which new technology may render jobs more scare, must be factored into the equation. Accident compensation took income support to higher income brackets. Is this preferable to redistribution to the less welloff? Levels of immigration pose issues as well, what are our obligations to people who arrive here? The prospect of increased migration caused by climate change in the future cannot be dismissed.

51 Hon Steven Joyce and Hon Judith Collins Making Tax Simpler: Better Administration of Social Policy (Policy and Strategy, Inland Revenue, July 2017); Inland Revenue Department "Proposals to improve social policy" (17 July 2017) <taxpolicy.ird.govt.nz>; and Inland Revenue Department "Archived websites: Making tax simpler" <taxpolicy.ird.govt.nz >. See also the Best Start tax credit, legislated for via the Families Package (Income Tax and Benefits) Act 2017; Inland Revenue Department "Best Start" < www.ird.govt.nz>; Work and Income "Families Package" (14 December 2017) < www.workandincome.govt.nz>; and Inland Revenue Department "Can I get Working for Families?" < www.ird.govt.nz>

52 Ron Paterson Warrant of Fitness: An Independent Review of the Veteran's Support Act 2014 (March 2018).

53 Gail E Duncan Economic Review of the Status of Beneficiaries in New Zealand (10 August 2018). 


\section{H Lessons for Policy-makers}

There are important lessons for policymakers embedded in the New Zealand experience with the accident compensation scheme. Unexpected results come with any scheme of this character. Lofty aims can easily be blown off course. Changing political ideologies, administrative blunders and constant legislative fiddling over time lead to incoherence.

Claimants have encountered serious difficulties in securing quick and fair decisions from a scheme that promised to provide decisions without technicality. Lines have to be drawn as the policy now stands, but those lines between injury and disease are frequently problematic and seem unfair to claimants.

The ACC scheme has made a major impact on the public health system. It provides funds for private medical providers by paying for treatment in private hospital and rehabilitation services, thus getting people back to work more quickly than could be achieved by the public health system. In this way the scheme has challenged the public health system and assisted private health providers.

The scheme has certainly improved the plight of accident victims compared to what was available at common law. Many more people can claim and have their hardship relieved. Yet there have been persistent criticisms of ACC in recent years about how the lines that are drawn, how medical issues are assessed and many changes in administration. In the last few years, the decisions of ACC have become more restrictive, similar to liability insurance not social insurance and less people-oriented. At its inception the scheme created two classes: those who are injured who are treated more generously than those who are sick or otherwise disabled. The Woodhouse Report made clear the recommended scheme was to be a temporary order of things. Until the discrimination the present scheme creates is removed, social justice will not have been achieved.

The abandonment of tort actions remains the legally most significant aspect of the scheme, and the policy of rejecting the tort system has been a constant feature of the New Zealand landscape since the enactment of the scheme. In no other common law jurisdiction has that policy advance been achieved. The policy in New Zealand has survived several attacks upon it. All sides of politics seem unanimous on not reintroducing tort litigation for personal injury.

The ultimate issue that is raised by the accident compensation scheme in New Zealand is one of social philosophy. The 1967 Woodhouse Report was based on the principle of community responsibility. The question is how should that principle be translated for a different world more than fifty years after the Report? We do not seem to be willing to grasp the nettle and design what a rational and humane system of income support looks like. Fairness demands a policy response and one that is properly worked through. That is what the Woodhouse legacy is saying to us, if only we would listen.

The Woodhouse vision was admirable, the performance of the scheme that was adopted improved matters substantially for accident victims but there is unfinished business. The future remains uncertain. We need now a fresh infusion of Woodhouse boldness and vision. 